\title{
Effect of the Aerosol-Phase State on Secondary Organic Aerosol Formation from the Reactive Uptake of Isoprene-Derived Epoxydiols (IEPOX)
}

Yue Zhang, ${ }^{*}, \dagger$ Yuzhi Chen, ${ }^{\dagger}$ Andrew T. Lambe, ${ }^{\ddagger}$ (i) Nicole E. Olson, ${ }^{\S}$ Ziying Lei, ${ }^{\prime \prime}$ Rebecca L. Craig, Zhenfa Zhang, $^{\dagger}$ Avram Gold, ${ }^{\dagger}$ Timothy B. Onasch, ${ }^{\ddagger} \perp$ John T. Jayne, ${ }^{\ddagger}$ Douglas R. Worsnop, Cassandra J. Gaston, ${ }^{\# \oplus}$ Joel A. Thornton, ${ }^{\circledR \oplus}$ William Vizuete, ${ }^{\dagger \odot}$ Andrew P. Ault, $,{ }^{*},, \|_{\odot}$ and Jason D. Surratt* ${ }^{*}+(1)$

${ }^{\dagger}$ Department of Environmental Sciences and Engineering, Gillings School of Global Public Health, University of North Carolina at Chapel Hill, Chapel Hill, North Carolina 27599, United States

${ }^{\ddagger}$ Aerodyne Research Inc., Billerica, Massachusetts 01821, United States

${ }^{\S}$ Department of Chemistry, College of Literature, Science, and the Arts, University of Michigan, Ann Arbor, Michigan 48109, United States

"Department of Environmental Health Sciences, School of Public Health, University of Michigan, Ann Arbor, Michigan 48109, United States

${ }^{\perp}$ Department of Chemistry, Boston College, Chestnut Hill, Massachusetts 02459, United States

\# Department of Atmospheric Sciences, The Rosenstiel School of Marine and Atmospheric Science, University of Miami, Miami, Florida 33149, United States

${ }^{\circledR}$ Department of Atmospheric Sciences, University of Washington, Seattle, Washington 98195, United States

\section{Supporting Information}

\begin{abstract}
Acid-catalyzed reactions between gas- and particle-phase constituents are critical to atmospheric secondary organic aerosol (SOA) formation. The aerosol-phase state is thought to influence the reactive uptake of gas-phase precursors to aerosol particles by altering diffusion rates within particles. However, few experimental studies have explored the precise role of the aerosol-phase state on reactive uptake processes. This laboratory study systematically examines the reactive uptake coefficient $(\gamma)$ of trans- $\beta$-isoprene epoxydiol (trans- $\beta$-IEPOX), the predominant IEPOX isomer, on acidic sulfate particles coated with SOA derived from $\alpha$-pinene ozonolysis. $\gamma_{\text {IEPOX }}$ is obtained for core-shell particles, the morphology of which was confirmed by microscopy, as a function of SOA coating thickness and relative humidity. $\gamma_{\text {IEPOX }}$ is reduced, in some cases by half of the original value, when SOA coatings are present prior to uptake, especially when coating thicknesses are $>15 \mathrm{~nm}$. The diurnal trend of IEPOX lost to acid-catalyzed reactive uptake yielding SOA compared with other known atmospheric sinks (gas-phase oxidation or deposition) is derived by modeling the experimental coating effect with field data from the southeastern United States. IEPOX-derived SOA is estimated to be reduced by $16-27 \%$ due to preexisting organic coatings during the afternoon (12:00 to 7:00 p.m., local time), corresponding to the period with the highest level of production.
\end{abstract}

\section{INTRODUCTION}

Isoprene is the most abundant non-methane volatile organic compound emitted into Earth's atmosphere, with annual estimated emissions ranging from 500 to $750 \mathrm{Tg} .{ }^{1}$ During the daytime, isoprene oxidation is typically dominated by a reaction with hydroxyl $(\mathrm{OH})$ radicals, ${ }^{2}$ where the resultant firstgeneration isoprene peroxy $\left(\mathrm{RO}_{2}\right)$ radicals subsequently react with hydroperoxy $\left(\mathrm{HO}_{2}\right)$ radicals or nitric oxide (NO) to produce low-volatility oxidation products, including isoprene epoxydiols (IEPOX) and methacrylic acid epoxide (MAE)/ hydroxymethylmethyl- $\alpha$-lactone (HMML). ${ }^{3-5}$ Recent studies have shown that reactive uptake of IEPOX onto an acidified sulfate particle can subsequently produce low-volatility polyols, organosulfates, and oligomeric products, making isoprene a significant source of secondary organic aerosol (SOA) in areas

Received: January 24, 2018

Revised: February 7, 2018

Accepted: February 8, 2018

Published: February 8, 2018 
where particles containing sulfate are common. ${ }^{3,6-14}$ This pathway accounts for up to $41 \%$ of the total organic mass fraction of submicrometer aerosol collected during the summer in the southeastern United States. ${ }^{15,16}$

The reactive uptake coefficient, $\gamma$, is an important parameter in modeling the production of SOA from heterogeneous reactions. ${ }^{17-19}$ Recent studies have exclusively measured the reactive uptake coefficient of IEPOX $\left(\gamma_{\text {IEPOX }}\right)$ on inorganic aerosol particles. ${ }^{18,20}$ These studies have provided useful information regarding the extent of IEPOX uptake on pure sulfate particles across a range of acidity and relative humidity (RH) levels. Modeling results combined with experimental data demonstrate that the heterogeneous reaction of IEPOX with sulfate particles is a dominant pathway for isoprene SOA formation at atmospherically relevant aerosol acidities and surface area concentrations. ${ }^{6,18,21,22}$

However, acidic sulfate particles rarely exist in pure form in the polluted boundary layer, as they are typically mixed with other organic and inorganic species, ${ }^{23}$ even in pristine forested, continental locations, such as during the 2013 Southern Oxidant and Aerosol Study (SOAS). ${ }^{24}$ After partitioning or aqueous formation of secondary organic material, mixed inorganic-organic aerosols may undergo phase separation under certain conditions due to either condensation or "salting out" of the inorganic component. ${ }^{25-30}$ Monoterpenes are important biogenic SOA precursors that are often co-emitted with isoprene. The monoterpenes undergo atmospheric oxidation to form low-volatility products that subsequently condense onto existing inorganic particles. ${ }^{2,31}$ The organic coating of the acidic sulfate particles has been assumed to be a liquid. ${ }^{30-32}$ However, evidence has recently been presented that both laboratory-generated and atmospheric SOA particles can be semisolid or glassy, depending on the $\mathrm{RH}$ and temperature. ${ }^{33-39}$ Ambient data obtained from field campaigns, such as the SOAS, show that RH during the daytime, especially during the afternoon (12:00 to 7:00 p.m., local time) when the level of IEPOX SOA formation is the greatest, consistently remains between 50 and $60 \%$, while nighttime $\mathrm{RH}$ increases to $90 \%{ }^{40}$ Field campaigns from the boreal forests show similar or even lower RH levels during the day than in the southeastern United States. $^{41,42}$ The relatively low RH during the daytime likely leads to a change in the aerosol-phase state and the rate of diffusion of IEPOX into the phase-separated inorganic-organic aerosol particles, which has potentially important implications for how efficiently isoprene-derived SOA can be produced via heterogeneous reactions. ${ }^{4-46}$ While previous studies ${ }^{18,46-50}$ used organic aerosol surrogates to study how an organic coating affects the reactive uptake of $\mathrm{HO}_{2}$ and $\mathrm{N}_{2} \mathrm{O}_{5}$ as well as IEPOX on particles, there have been no systematic studies to derive $\gamma_{\text {IEPOX }}$ and to understand the effects of atmospherically relevant SOA coatings on IEPOX-derived SOA formation. Riva et al. recently demonstrated that $\alpha$-pinene SOA could impede the reactive uptake of IEPOX, ${ }^{51}$ but measurements of the reactive uptake kinetics $\left(\gamma_{\text {IEPOX }}\right)$ and the morphology of the internally mixed particles are needed to further develop predictive models of IEPOX-derived SOA formation.

In this study, we measured the reactive uptake of trans- $\beta$ IEPOX on submicrometer acidic sulfate particles that were coated with $\alpha$-pinene SOA at atmospherically relevant coating thicknesses and selected RHs. Our measurements demonstrate that the coating thickness of SOA and $\mathrm{RH}$ have significant effects on $\gamma_{\text {IEPOX }}$ during the experimental time scale. The data are parametrized using a core-shell resistor model, based on the observation that a uniform layer of organics is coated onto the acidic sulfate particles using the potential aerosol mass (PAM) oxidation flow reactor, confirmed via atomic force microscopy (AFM) and scanning electron microscopy (SEM). A zerodimensional box model was used to assess the fraction of IEPOX forming SOA among all atmospheric sinks of IEPOX by combining experimental data with ambient measurements from the 2013 SOAS campaign. Our results provide experimental evidence of the effect of SOA coatings on the reactive uptake of IEPOX onto SOA-coated acidic sulfate particles at different coating thicknesses and $\mathrm{RH}$ conditions, and the impact of organic coatings on IEPOX-derived SOA formation.

\section{MATERIALS AND METHODS}

The experimental setup consists of three components: aerosol generation and coating with SOA, IEPOX reactive uptake, and analytical instruments for gas- and particle-phase chemical measurements, including determination of particle morphology. A schematic plot of the experimental setup is shown in Figure S1, and a detailed description of each component is briefly summarized below.

2.1. Aerosol Generation and Characterization. Aerosols were generated from a solution of $0.06 \mathrm{M}$ ammonium sulfate (Sigma-Aldrich, $\geq 99 \%$ pure) mixed with an equivalent concentration of sulfuric acid (Sigma-Aldrich, $\geq 98 \%$ pure) using a constant output atomizer (TSI Inc., model 3076) operated at $3 \mathrm{~L} / \mathrm{min}$ with purified air. An aerosol flow passed through a diffusion drier and a differential mobility analyzer (DMA, TSI Inc., model 3080) before entering the PAM reactor (Aerodyne Research, Inc.). In this experiment, the PAM was used as a continuous flow reactor to coat acidic sulfate particles with secondary organic materials derived from $\alpha$-pinene ozonolysis. Particles with an electrical mobility diameter of $100 \mathrm{~nm}$ were selected by the DMA and subsequently coated inside the PAM reactor (Figure S2). Operating conditions of the PAM were similar to those described by Lambe et al. ${ }^{52}$ (details in the Supporting Information).

2.2. IEPOX Uptake Measurements. $\gamma_{\text {IEPOX }}$ was measured using a cylindrical glass laminar flow reactor $(1 \mathrm{~m}$ length $\times 8$ $\mathrm{cm}$ inside diameter) coated with halocarbon wax (Halocarbon Products Corp.) to minimize wall loss of the gas-phase IEPOX. The operating procedures and calculation of $\gamma_{\text {IEPOX }}$ were similar to those previously described. ${ }^{18,20}$ Details are summarized in the Supporting Information (eqs S1 and S2 and Figure S3).

2.3. Morphology from Microscopy Imaging. Aerosol particle samples were collected prior to IEPOX reactive uptake to confirm core-shell structure. A three-stage microanalysis particle sampler (MPS-3, California Measurements, Inc.) with size cuts of 5.0, 2.5, and $0.4 \mu \mathrm{m}$ was operated at $2.1 \mathrm{~L} \mathrm{~min}^{-1}$. Particles were impacted onto carbon-type-b Formvar-coated copper transmission electron microscopy (TEM) grids and silicon wafer substrates (Ted Pella, Inc.). Samples were stored in sealed plastic vials at room temperature prior to analysis. An FEI Helios 650 Nanolab-Dualbeam electron microscope equipped with a high-angle annular dark field (HAADF) detector operated at an accelerating voltage of $10.0 \mathrm{kV}$, a current of $0.80 \mathrm{nA}$, and pressures ranging from $10^{-3}$ to $10^{-5} \mathrm{~Pa}$ was used to analyze TEM grids. Particles on silicon substrates were imaged in $5 \mu \mathrm{m} \times 5 \mu \mathrm{m}$ regions by an atomic force microscope (Anasys Instruments) in tapping mode with a $75 \pm$ $15 \mathrm{kHz}$ resonant frequency and a $1-7 \mathrm{~N} \mathrm{~m}^{-1}$ spring constant ${ }^{53}$ at ambient laboratory temperature $\left(\sim 23^{\circ} \mathrm{C}\right)$, pressure, and $\mathrm{RH}$ ( 36\%). 


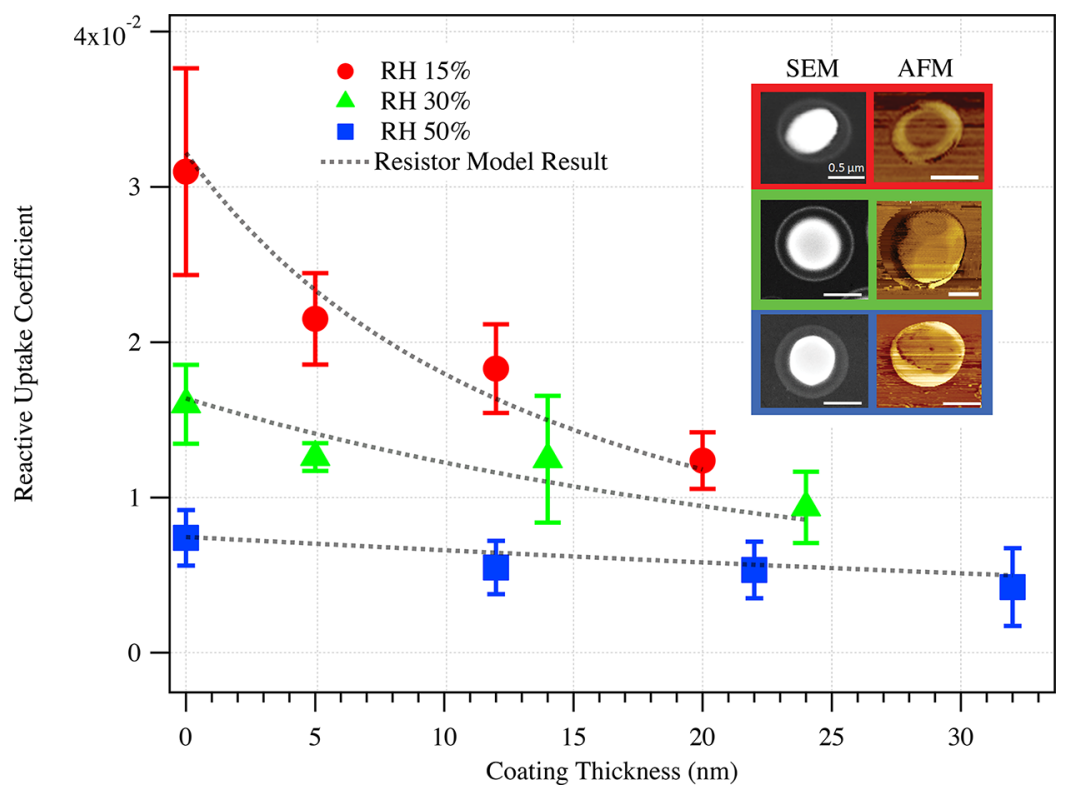

Figure 1. $\gamma_{\mathrm{IEPOX}}$ as a function of $\alpha$-pinene SOA coating thickness and $\mathrm{RH}$. The red, green, and blue data points and box outlines represents 15,30 , and $50 \% \mathrm{RH}$ conditions, respectively. The black dashed line represents the predicted $\gamma_{\text {IEPOX }}$ using an inorganic core-organic shell morphology resistor model. The inset shows the SEM images (left column) and AFM phase images (right column) of $\alpha$-pinene SOA-coated acidic sulfate particles from these three RH levels. The images correspond to those data points having coating thicknesses ranging from 10 to $13 \mathrm{~nm}$ as shown in the figure. All scale bars in the images represent the same length of $0.5 \mu \mathrm{m}$.

\section{RESULTS AND DISCUSSION}

\subsection{Morphology of SOA-Coated Acidic Sulfate}

Particles. SEM and AFM images demonstrated the coreshell particle morphology after acidic sulfate particles were exposed to products of $\alpha$-pinene ozonolysis, resulting in the formation of a coating or a separate organic phase. ${ }^{54-56}$ Inset images in Figure 1 show SOA-coated acidic sulfate particles after RH conditioning by the Nafion driers, but prior to exposure of trans- $\beta$-IEPOX. The left column shows particles exposed to $200-400 \mathrm{ppb} \alpha$-pinene under three $\mathrm{RH}$ conditions $(15,30$, and $50 \%)$, imaged via SEM, ${ }^{57,58}$ while the right column shows ambient-pressure AFM phase imaging of particles exposed at the same $\alpha$-pinene concentrations and $\mathrm{RH}$ conditions. Particles with volume equivalent diameters of $\sim 75-100 \mathrm{~nm}$ (based on projected area diameters of $\sim 300 \mathrm{~nm}$ and typical spreading ratios ${ }^{56,59}$ ) exhibit phase separation after exposure to $\alpha$-pinene for all $\mathrm{RH}$ conditions analyzed. Height and amplitude AFM images of particles with the core-shell morphology are included in Figure S4. The morphological information obtained by SEM and AFM confirms the coating of $\alpha$-pinene SOA on the $100 \mathrm{~nm}$ acidic inorganic particles leads predominantly to a core-shell morphology.

3.2. $\gamma_{\text {IEPOX }}$ Kinetics as a Function of Relative Humidity and Coating Thickness. Figure 1 shows IEPOX reactive uptake results obtained at specific $\mathrm{RH}$ levels and SOA coating thicknesses. Experimental $\mathrm{RH}$ values were 15, 30, and 50\%, with $\alpha$-pinene SOA coating thickness ranging from 0 to $32 \mathrm{~nm}$. At a zero SOA coating thickness, IEPOX reactive uptake of pure acidic sulfate particles was inversely related to $\mathrm{RH}$, in agreement with previous studies. ${ }^{18,20}$ For pure acidic sulfate particles, as RH increases, aerosol particles take up more water, increasing the total surface area and diluting particle acidity, both of which reduce $\gamma_{\text {IEPOX }}$.

At the same RH level, the SOA coating thickness and $\gamma_{\text {IEPOX }}$ were negatively correlated. At $15 \% \mathrm{RH}, \gamma_{\mathrm{IEPOX}}$ decreased from $(31 \pm 7) \times 10^{-3}$ to $(12 \pm 2) \times 10^{-3}$ as the SOA coating thickness increased from 0 to $20 \mathrm{~nm}$. At $50 \% \mathrm{RH}$, for roughly the same increase in SOA coating thickness, $\gamma_{\text {IEPOX }}$ decreased from $(7 \pm 2) \times 10^{-3}$ to $(4 \pm 3) \times 10^{-3}$, approaching the detection limit of the current analytical method. For $\alpha$-pinene SOA-coated particles, $\gamma_{\text {IEPOx }}$ was reduced $30-50 \%$ by an only $\sim 15 \mathrm{~nm}$ coating on the acidic sulfate particles for each RH level examined. $\gamma_{\text {IEPOX }}$ was also measured on pure $\alpha$-pinene SOA to account for the fraction of IEPOX uptake from $\alpha$-pinene SOA, and the value was determined to be negligible within the range of error (see Table S1). As the SOA coating thickness was the only variable and uptake by $\alpha$-pinene SOA was negligible, the decrease in $\gamma_{\text {IEPOX }}$ can be explained by the resistance to the diffusion of IEPOX through the SOA coating before it reaches the acidic sulfate core. As the diffusion time scale of dissolved IEPOX through the coating increased, the extent of heterogeneous reaction decreased, thereby reducing $\gamma_{\text {IEPOX }}$. Figure 1 shows that at lower RHs, the decrease in $\gamma_{\text {IEPOX }}$ is larger than at higher RHs. This observation can be explained by the fact that as $\mathrm{RH}$ increases, the viscosity of $\alpha$-pinene SOA decreases, ${ }^{33,34}$ leading to an increase in the IEPOX diffusion rate and a less dramatic decrease in $\gamma_{\text {IEPOX }}$. Our results support the dependence of acid-catalyzed multiphase chemistry of IEPOX on the coating thickness and the phase state of $\alpha$ pinene SOA, with the SOA-phase state being determined by the composition and RH.

3.3. Atmospheric Implications of SOA Coatings on Heterogeneous Reactions of IEPOX. On the basis of the core-shell morphology determined by SEM and AFM, a resistor model from previous studies that includes the diffusion of reactive gas from the shell to the particle core was applied to our results for parametrization: ${ }^{46,50}$

$$
\frac{1}{\gamma}=\frac{R_{\mathrm{p}} \omega}{4 D_{\mathrm{gas}}}+\frac{1}{\alpha}+\frac{1}{\Gamma_{\mathrm{aq}}}+\frac{1}{\Gamma_{\mathrm{org}}}
$$

The detailed explanation and the calculation of eq 1 are provided in the Supporting Information. Via application of eq 1 


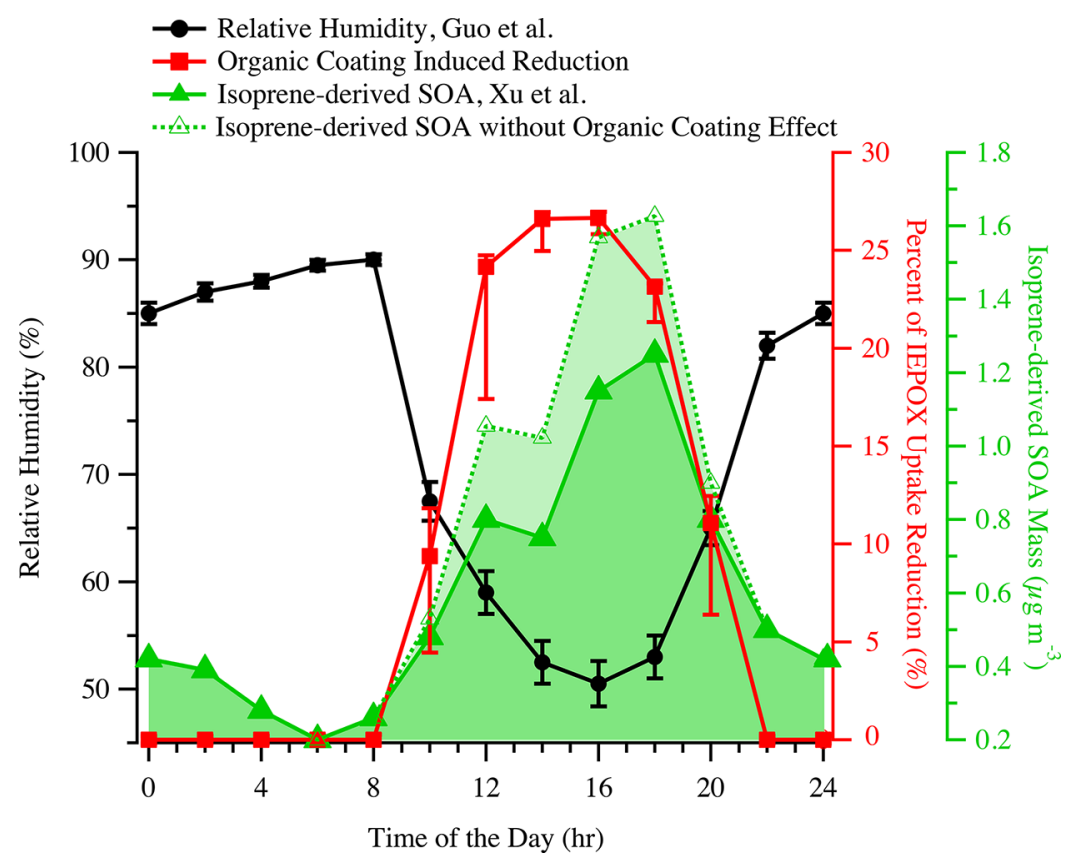

Figure 2. Atmospheric implications of this study. Diurnal trend of the fraction of IEPOX that undergoes reactive uptake when the SOA coating effect is considered compared with the same situation when the SOA coating is not considered. The black line shows the ambient RH measured during the 2013 SOAS campaign by Guo et al. $^{40}$ The red line shows the percent of reduction of IEPOX uptake caused by the coating effect. The green filled triangles represent the IEPOX-derived SOA mass concentrations measured during the 2013 SOAS campaign when there was a preexisting organic coating on the aerosols. ${ }^{16}$ The green empty triangles represent the IEPOX-derived SOA mass loading assuming no preexisting organic coating on the ambient aerosol.

to the $\gamma_{\text {IEPOX }}$ values obtained under each $\mathrm{RH}$ condition, the resistor model is used to match the fit of the experimental data, represented by the black dashed lines in Figure 1. The detailed parametrization is shown in Table S2. With reasonable parametrization, minimal differences between the fitted lines and data points demonstrate that the core-shell morphology resistor modeling approach is appropriate and consistent with the microscopy results depicted in Figure 1. The resistor model shows how the diffusion of IEPOX in the SOA coating affects the reactive uptake process and heterogeneous chemistry as the $\mathrm{RH}$ changes.

Besides acid-catalyzed reactive uptake of IEPOX on existing sulfate particles, two other major atmospheric sinks for IEPOX include gas-phase oxidation by $\mathrm{OH}$ radicals and natural surface deposition. The reaction rate constants for these latter two atmospheric sinks are as follows: $k_{\mathrm{OH}}=0.84-3.4 \times 10^{-11} \mathrm{~cm}^{3}$ molecule ${ }^{-1} \mathrm{~s}^{-160,61}$ and $k_{\mathrm{dep}}=2.5 \times 10^{-5} \mathrm{~s}^{-1}$, ${ }^{62}$ respectively. The rate of heterogeneous reaction of IEPOX with varying SOA coating thicknesses, $k_{\text {het,coating }}$ is calculated by combining eq 1 with eqs S3 and S4. The fraction of IEPOX lost to acidcatalyzed reactive uptake on existing particles compared with total IEPOX sinks, $f$, can be expressed as

$$
f=k_{\text {het,coating }} /\left([\mathrm{OH}] k_{\mathrm{OH}}+k_{\text {dep }}+k_{\text {het,coating }}\right)
$$

Using this parametrization and assuming the $\mathrm{pH}$ of the ambient aerosol ranges between 0 and $2,^{63}$ Figures S5 and S6 show the fraction of IEPOX lost to acid-catalyzed reactive uptake among the total IEPOX sinks for the three $\mathrm{RH}$ conditions measured in the experiments as a function of surface area and SOA coating thickness.

To further understand the impacts of preexisting SOA coatings on the reactive uptake of IEPOX, we applied ambient data collected from the 2013 SOAS campaign to our model estimations. Xu et al. reported that monoterpene SOA accounts for $24-49 \%$ of the total OA in the southeastern United States and is likely to coat the existing inorganic sulfate particles due to a lack of new particle formation events in the summer. ${ }^{64} \mathrm{~A}$ comparison of IEPOX-derived SOA with and without an organic coating, together with diurnal $\mathrm{RH}$ variations based on field measurements taken during the 2013 SOAS campaign at the Centerville, AL, ground site, is shown in Figure 2. These data suggest that the $\mathrm{RH}$ in the southeastern United States remains between 50 and $60 \%$ during the afternoon (12:00 to 7:00 p.m., local time) and increases to $80-90 \%$ at night and early morning. $\gamma_{\text {IEPOX }}$ at $50 \% \mathrm{RH}$ is obtained from data in this study, and $\gamma_{\text {IEPOX }}$ values at $60-80 \% \mathrm{RH}$ were conservatively estimated on the basis of combining $\gamma_{\text {IEPOX }}$ values at 30 and $50 \% \mathrm{RH}$ determined in this study with the viscosity data of $\alpha$ pinene SOA measured by Renbaum-Wolff et al., ${ }^{33}$ with details provided in the Supporting Information (eq S5 and Figure S7). We set the viscosity of $\alpha$-pinene SOA in our model to be the lower-bound viscosity values measured by Renbaum-Wolff et al. at $80-90 \% \mathrm{RH}$ or higher (no diffusion limitation of IEPOX) to conservatively estimate the effect of phase on the acid-catalyzed heterogeneous formation of IEPOX-derived SOA. ${ }^{33}$ Note that the viscosity values provided by Renbaum-Wolff et al. were derived from water-soluble components of $\alpha$-pinene SOA, indicating the viscosity of total $\alpha$-pinene SOA is likely to be even higher. ${ }^{33}$ Thus, our study provides a conservative estimate of $\gamma_{\text {IEPOX }}$ as $\mathrm{RH}$ ranges from 60 to $90 \%$. A higher viscosity value, as shown in Figure S7 from our calculations, could decrease $\gamma_{\text {IEPOX }}$ by $3 \times 10^{-3}$ for every order of magnitude of increase in viscosity, indicating an even stronger phase effect. As a result, future experiments are needed to provide more accurate estimates of the effect of an organic phase on IEPOX uptake in a high- $\mathrm{RH}(>50 \%)$ environment. The average organic coating thickness during the 2013 SOAS campaign is estimated to be 
$16 \mathrm{~nm}$ by the calculation of coating thickness using eq S6. We assume $\alpha$-pinene SOA is representative of the monoterpene organic coating in the southeastern United States, because $\alpha$ pinene is one of the dominant monoterpenes. ${ }^{16}$ Further details of modeling and parametrization of the diurnal $\mathrm{OH}$ concentration and diffusion coefficients are shown in Table S3 and Figures S8 and S9. With the diffusion coefficients of IEPOX calculated for each $\mathrm{RH}$ bin, the diurnal profile of IEPOX that undergoes reactive uptake to form SOA is obtained from eq 2 and shown in Figure 2. As shown by $\mathrm{Xu}$ et al., ${ }^{16}$ ambient IEPOX-derived SOA has a large diurnal variation, with more than half forming in the afternoon (12:00 to 7:00 p.m., local time) when the $\mathrm{RH}$ remains between 50 and $60 \%$. Figure 2 shows that IEPOX-derived SOA would have increased by $16-27 \%$ without considering the effect of preexisting monoterpene SOA coatings during this time period. Hu et al. modeled the IEPOX uptake with preexisting PEG coatings, and results show an $\sim 20 \%$ reduction, which is consistent with the values reported here. ${ }^{65}$ Our study also provides a potential explanation for the discrepancy between model predictions and field measurements of IEPOX-derived SOA reported by Pye et al. and Budisulistiorini et al., where mass concentrations of 2methyltetrols, products of the reactive uptake of IEPOX, are reported to be overestimated by the Community Multiscale Air Quality (CMAQ)-based models compared to the field data from the 2013 SOAS campaign. ${ }^{17,66}$ This study indicates that at atmospheric conditions similar to those of the southeastern United States, SOA coatings on acidic sulfate particles could play an important role in governing the production of IEPOXderived SOA.

Our results suggest that the inorganic and organic components of the aerosol particles, as well as their physical and chemical properties, jointly impact the formation, evolution, and fate of the ambient SOA. For instance, as described in this study, preexisting SOA constituents formed from the condensation of semivolatile species, with a certain phase state and chemical kinetics, can adversely affect the reactive uptake of gases leading to the formation of additional SOA components. ${ }^{67}$ Given that the ambient RHs in other parts of the world, such as boreal forest, can be even lower than in the southeastern United States, ${ }^{68}$ the effects of the aerosolphase state on heterogeneous reactions, such as the inorganic/ organic mixtures examined in this study, are likely to be more prevalent in contrast to uptake observed for pure organic particles that have been recently reported. ${ }^{69}$ Currently, the influence of the aerosol-phase state for SOA types other than $\alpha$ pinene and at other $\mathrm{RH}$ values remains uncertain and warrants future study.

\section{ASSOCIATED CONTENT}

\section{S Supporting Information}

The Supporting Information is available free of charge on the ACS Publications website at DOI: 10.1021/acs.estlett.8b00044.

Tabulated experimental conditions and results, aerosol size distributions measured by the SMPS, natural logarithm of the IEPOX signal measured by HR-ToFCIMS, additional microscopic images, explanation of the resistor models, and model parametrization details (PDF)

\section{AUTHOR INFORMATION}

\section{Corresponding Authors}

*E-mail: surratt@unc.edu. Phone: 919-966-0470. Fax: 919-9667911.

*E-mail: aulta@umich.edu. Phone: 734-763-4212. Fax: 734936-7283.

*E-mail: yzhang01@live.unc.edu. Phone: 919-966-3861. Fax: 919-966-7911.

ORCID

Andrew T. Lambe: 0000-0003-3031-701X

Cassandra J. Gaston: 0000-0003-1383-8585

Joel A. Thornton: 0000-0002-5098-4867

William Vizuete: 0000-0002-1399-2948

Andrew P. Ault: 0000-0002-7313-8559

Jason D. Surratt: 0000-0002-6833-1450

\section{Notes}

The authors declare no competing financial interest.

\section{ACKNOWLEDGMENTS}

The authors thank Matthieu Riva, Penglin Ye, Wen Xu, Amy Bondy, Manjula Canagaratna, Jordan Krechmer, and Paul Davidovits for useful discussions and assistance with the experiments. SEM data were collected at the Michigan Center for Materials Characterization $\left(\mathrm{MC}^{2}\right)$. Assistance with AFM data analysis was provided by Prof. Mark Banaszak Holl at the University of Michigan. This work was funded by the National Science Foundation (NSF) under Atmospheric and Geospace Sciences (AGS) Grants 1703019 (A.P.A.) and 1703535 (J.D.S.). J.D.S. also acknowledges the NSF under Chemistry (CHE) Grant 1404644. The preparation of this research article was also funded in part by a grant from the Texas Air Quality Research Program (AQRP) at The University of Texas at Austin through the Texas Emissions Reduction Program (TERP) and the Texas Commission on Environmental Quality (TCEQ). Y.Z. was supported by the NSF Postdoctoral Fellowship under AGS Grant 1524731.

\section{REFERENCES}

(1) Guenther, A. B.; Jiang, X.; Heald, C. L.; Sakulyanontvittaya, T.; Duhl, T.; Emmons, L. K.; Wang, X. The Model of Emissions of Gases and Aerosols from Nature version 2.1 (MEGAN2.1): an extended and updated framework for modeling biogenic emissions. Geosci. Model Dev. 2012, 5 (6), 1471-1492.

(2) Atkinson, R.; Arey, J. Gas-phase tropospheric chemistry of biogenic volatile organic compounds: a review. Atmos. Environ. 2003, 37, 197-219.

(3) Paulot, F.; Crounse, J. D.; Kjaergaard, H. G.; Kurten, A.; St. Clair, J. M.; Seinfeld, J. H.; Wennberg, P. O. Unexpected epoxide formation in the gas-phase photooxidation of isoprene. Science 2009, 325 (5941), $730-733$.

(4) Lin, Y. H.; Zhang, H.; Pye, H. O.; Zhang, Z.; Marth, W. J.; Park, S.; Arashiro, M.; Cui, T.; Budisulistiorini, S. H.; Sexton, K. G.; Vizuete, W.; Xie, Y.; Luecken, D. J.; Piletic, I. R.; Edney, E. O.; Bartolotti, L. J.; Gold, A.; Surratt, J. D. Epoxide as a precursor to secondary organic aerosol formation from isoprene photooxidation in the presence of nitrogen oxides. Proc. Natl. Acad. Sci. U. S. A. 2013, 110 (17), 67186723.

(5) Nguyen, T. B.; Bates, K. H.; Crounse, J. D.; Schwantes, R. H.; Zhang, X.; Kjaergaard, H. G.; Surratt, J. D.; Lin, P.; Laskin, A.; Seinfeld, J. H.; Wennberg, P. O. Mechanism of the hydroxyl radical oxidation of methacryloyl peroxynitrate (MPAN) and its pathway toward secondary organic aerosol formation in the atmosphere. Phys. Chem. Chem. Phys. 2015, 17 (27), 17914-17926. 
(6) Liu, Y.; Kuwata, M.; Strick, B. F.; Geiger, F. M.; Thomson, R. J.; McKinney, K. A.; Martin, S. T. Uptake of Epoxydiol Isomers Accounts for Half of the Particle-Phase Material Produced from Isoprene Photooxidation via the HO2 Pathway. Environ. Sci. Technol. 2015, 49 (1), 250-258

(7) Claeys, M.; Graham, B.; Vas, G.; Wang, W.; Vermeylen, R.; Pashynska, V.; Cafmeyer, J.; Guyon, P.; Andreae, M. O.; Artaxo, P.; Maenhaut, W. Formation of Secondary Organic Aerosols Through Photooxidation of Isoprene. Science 2004, 303 (5661), 1173-1176.

(8) Edney, E. O.; Kleindienst, T. E.; Jaoui, M.; Lewandowski, M.; Offenberg, J. H.; Wang, W.; Claeys, M. Formation of 2-methyl tetrols and 2-methylglyceric acid in secondary organic aerosol from laboratory irradiated isoprene/NOX/SO2/air mixtures and their detection in ambient PM2.5 samples collected in the eastern United States. Atmos. Environ. 2005, 39 (29), 5281-5289.

(9) Kroll, J. H.; Ng, N. L.; Murphy, S. M.; Flagan, R. C.; Seinfeld, J. $\mathrm{H}$. Secondary organic aerosol formation from isoprene photooxidation. Environ. Sci. Technol. 2006, 40 (6), 1869-1877.

(10) Kroll, J. H.; Ng, N. L.; Murphy, S. M.; Flagan, R. C.; Seinfeld, J. $\mathrm{H}$. Secondary organic aerosol formation from isoprene photooxidation under high-NOx conditions. Geophys. Res. Lett. 2005, 32 (18), L18808. (11) Surratt, J. D.; Murphy, S. M.; Kroll, J. H.; Ng, N. L.; Hildebrandt, L.; Sorooshian, A.; Szmigielski, R.; Vermeylen, R.; Maenhaut, W.; Claeys, M.; Flagan, R. C.; Seinfeld, J. H. Chemical composition of secondary organic aerosol formed from the photooxidation of isoprene. J. Phys. Chem. A 2006, 110 (31), 9665-9690.

(12) Surratt, J. D.; Chan, A. W.; Eddingsaas, N. C.; Chan, M.; Loza, C. L.; Kwan, A. J.; Hersey, S. P.; Flagan, R. C.; Wennberg, P. O.; Seinfeld, J. H. Reactive intermediates revealed in secondary organic aerosol formation from isoprene. Proc. Natl. Acad. Sci. U. S. A. 2010, 107 (15), 6640-6645.

(13) Lin, Y. H.; Zhang, Z.; Docherty, K. S.; Zhang, H.; Budisulistiorini, S. H.; Rubitschun, C. L.; Shaw, S. L.; Knipping, E. M.; Edgerton, E. S.; Kleindienst, T. E.; Gold, A.; Surratt, J. D. Isoprene epoxydiols as precursors to secondary organic aerosol formation: acidcatalyzed reactive uptake studies with authentic compounds. Environ. Sci. Technol. 2012, 46 (1), 250-258.

(14) Bondy, A. L.; Craig, R. L.; Zhang, Z.; Gold, A.; Surratt, J. D.; Ault, A. P. Isoprene-Derived Organosulfates: Vibrational Mode Analysis by Raman Spectroscopy, Acidity-Dependent Spectral Modes, and Observation in Individual Atmospheric Particles. J. Phys. Chem. A 2018, 122 (1), 303-315.

(15) Budisulistiorini, S. H.; Baumann, K.; Edgerton, E. S.; Bairai, S. T.; Mueller, S.; Shaw, S. L.; Knipping, E. M.; Gold, A.; Surratt, J. D. Seasonal characterization of submicron aerosol chemical composition and organic aerosol sources in the southeastern United States: Atlanta, Georgia,and Look Rock, Tennessee. Atmos. Chem. Phys. 2016, 16 (8), 5171-5189.

(16) Xu, L.; Guo, H.; Boyd, C. M.; Klein, M.; Bougiatioti, A.; Cerully, K. M.; Hite, J. R.; Isaacman-VanWertz, G.; Kreisberg, N. M.; Knote, C.; Olson, K.; Koss, A.; Goldstein, A. H.; Hering, S. V.; de Gouw, J.; Baumann, K.; Lee, S.-H.; Nenes, A.; Weber, R. J.; Ng, N. L. Effects of anthropogenic emissions on aerosol formation from isoprene and monoterpenes in the southeastern United States. Proc. Natl. Acad. Sci. U. S. A. 2015, 112 (1), 37-42.

(17) Pye, H. O. T.; Pinder, R. W.; Piletic, I. R.; Xie, Y.; Capps, S. L.; Lin, Y.-H.; Surratt, J. D.; Zhang, Z.; Gold, A.; Luecken, D. J.; Hutzell, W. T.; Jaoui, M.; Offenberg, J. H.; Kleindienst, T. E.; Lewandowski, M.; Edney, E. O. Epoxide Pathways Improve Model Predictions of Isoprene Markers and Reveal Key Role of Acidity in Aerosol Formation. Environ. Sci. Technol. 2013, 47 (19), 11056-11064.

(18) Gaston, C. J.; Riedel, T. P.; Zhang, Z.; Gold, A.; Surratt, J. D.; Thornton, J. A. Reactive Uptake of an Isoprene-Derived Epoxydiol to Submicron Aerosol Particles. Environ. Sci. Technol. 2014, 48 (19), $11178-11186$.

(19) Kolb, C. E.; Cox, R. A.; Abbatt, J. P. D.; Ammann, M.; Davis, E. J.; Donaldson, D. J.; Garrett, B. C.; George, C.; Griffiths, P. T.; Hanson, D. R.; Kulmala, M.; McFiggans, G.; Pöschl, U.; Riipinen, I.; Rossi, M. J.; Rudich, Y.; Wagner, P. E.; Winkler, P. M.; Worsnop, D.
R.; O'Dowd, C. D. O' Dowd, C. D., An overview of current issues in the uptake of atmospheric trace gases by aerosols and clouds. Atmos. Chem. Phys. 2010, 10 (21), 10561-10605.

(20) Riedel, T. P.; Lin, Y.-H.; Budisulistiorini, S. H.; Gaston, C. J.; Thornton, J. A.; Zhang, Z.; Vizuete, W.; Gold, A.; Surratt, J. D. Heterogeneous Reactions of Isoprene-Derived Epoxides: Reaction Probabilities and Molar Secondary Organic Aerosol Yield Estimates. Environ. Sci. Technol. Lett. 2015, 2 (2), 38-42.

(21) Riedel, T. P.; Lin, Y. H.; Zhang, Z.; Chu, K.; Thornton, J. A.; Vizuete, W.; Gold, A.; Surratt, J. D. Constraining condensed-phase formation kinetics of secondary organic aerosol components from isoprene epoxydiols. Atmos. Chem. Phys. 2016, 16 (3), 1245-1254.

(22) Lin, Y. H.; Zhang, Z.; Docherty, K. S.; Zhang, H.; Budisulistiorini, S. H.; Rubitschun, C. L.; Shaw, S. L.; Knipping, E. M.; Edgerton, E. S.; Kleindienst, T. E.; Gold, A.; Surratt, J. D. Isoprene Epoxydiols as Precursors to Secondary Organic Aerosol Formation: Acid-Catalyzed Reactive Uptake Studies with Authentic Compounds. Environ. Sci. Technol. 2012, 46 (1), 250-258.

(23) Hatch, L. E.; Creamean, J. M.; Ault, A. P.; Surratt, J. D.; Chan, M. N.; Seinfeld, J. H.; Edgerton, E. S.; Su, Y.; Prather, K. A. Measurements of Isoprene-Derived Organosulfates in Ambient Aerosols by Aerosol Time-of-Flight Mass Spectrometry - Part 1: Single Particle Atmospheric Observations in Atlanta. Environ. Sci. Technol. 2011, 45 (12), 5105-5111.

(24) Craig, R. L.; Bondy, A. L.; Ault, A. P. Computer-controlled Raman microspectroscopy (CC-Raman): A method for the rapid characterization of individual atmospheric aerosol particles. Aerosol Sci. Technol. 2017, 51 (9), 1099-1112.

(25) Ault, A. P.; Axson, J. L. Atmospheric Aerosol Chemistry: Spectroscopic and Microscopic Advances. Anal. Chem. 2017, 89 (1), 430-452.

(26) O’Brien, R. E.; Wang, B.; Kelly, S. T.; Lundt, N.; You, Y.; Bertram, A. K.; Leone, S. R.; Laskin, A.; Gilles, M. K. Liquid-Liquid Phase Separation in Aerosol Particles: Imaging at the Nanometer Scale. Environ. Sci. Technol. 2015, 49 (8), 4995-5002.

(27) Smith, M. L.; You, Y.; Kuwata, M.; Bertram, A. K.; Martin, S. T. Phase Transitions and Phase Miscibility of Mixed Particles of Ammonium Sulfate, Toluene-Derived Secondary Organic Material, and Water. J. Phys. Chem. A 2013, 117 (36), 8895-8906.

(28) Ryder, O. S.; Ault, A. P.; Cahill, J. F.; Guasco, T. L.; Riedel, T. P.; Cuadra-Rodriguez, L. A.; Gaston, C. J.; Fitzgerald, E.; Lee, C.; Prather, K. A.; Bertram, T. H. On the Role of Particle Inorganic Mixing State in the Reactive Uptake of N2O5 to Ambient Aerosol Particles. Environ. Sci. Technol. 2014, 48 (3), 1618-1627.

(29) Renbaum-Wolff, L.; Song, M.; Marcolli, C.; Zhang, Y.; Liu, P. F.; Grayson, J. W.; Geiger, F. M.; Martin, S. T.; Bertram, A. K. Observations and implications of liquid-liquid phase separation at high relative humidities in secondary organic material produced by $\alpha$ pinene ozonolysis without inorganic salts. Atmos. Chem. Phys. 2016, 16 (12), 7969-7979.

(30) You, Y.; Renbaum-Wolff, L.; Carreras-Sospedra, M.; Hanna, S. J.; Hiranuma, N.; Kamal, S.; Smith, M. L.; Zhang, X.; Weber, R. J.; Shilling, J. E.; Dabdub, D.; Martin, S. T.; Bertram, A. K. Images reveal that atmospheric particles can undergo liquid-liquid phase separations. Proc. Natl. Acad. Sci. U. S. A. 2012, 109 (33), 13188-13193.

(31) Hallquist, M.; Wenger, J. C.; Baltensperger, U.; Rudich, Y.; Simpson, D.; Claeys, M.; Dommen, J.; Donahue, N. M.; George, C.; Goldstein, A. H.; Hamilton, J. F.; Herrmann, H.; Hoffmann, T.; Iinuma, Y.; Jang, M.; Jenkin, M. E.; Jimenez, J. L.; Kiendler-Scharr, A.; Maenhaut, W.; McFiggans, G.; Mentel, T. F.; Monod, A.; Prévôt, A. S. H.; Seinfeld, J. H.; Surratt, J. D.; Szmigielski, R.; Wildt, J. The formation, properties and impact of secondary organic aerosol: current and emerging issues. Atmos. Chem. Phys. 2009, 9 (14), 5155-5236.

(32) Odum, J. R.; Hoffmann, T.; Bowman, F.; Collins, D.; Flagan, R. C.; Seinfeld, J. H. Gas/Particle Partitioning and Secondary Organic Aerosol Yields. Environ. Sci. Technol. 1996, 30 (8), 2580-2585.

(33) Renbaum-Wolff, L.; Grayson, J. W.; Bateman, A. P.; Kuwata, M.; Sellier, M.; Murray, B. J.; Shilling, J. E.; Martin, S. T.; Bertram, A. K. Viscosity of $\alpha$-pinene secondary organic material and implications for 
particle growth and reactivity. Proc. Natl. Acad. Sci. U. S. A. 2013, 110 (20), 8014-8019.

(34) Zhang, Y.; Sanchez, M. S.; Douet, C.; Wang, Y.; Bateman, A. P.; Gong, Z.; Kuwata, M.; Renbaum-Wolff, L.; Sato, B. B.; Liu, P. F.; Bertram, A. K.; Geiger, F. M.; Martin, S. T. Changing shapes and implied viscosities of suspended submicron particles. Atmos. Chem. Phys. 2015, 15 (14), 7819-7829.

(35) Rothfuss, N. E.; Petters, M. D. Characterization of the temperature and humidity-dependent phase diagram of amorphous nanoscale organic aerosols. Phys. Chem. Chem. Phys. 2017, 19 (9), 6532-6545.

(36) Pajunoja, A.; Malila, J.; Hao, L.; Joutsensaari, J.; Lehtinen, K. E. J.; Virtanen, A. Estimating the viscosity range of SOA particles based on their coalescence time. Aerosol Sci. Technol. 2014, 48 (2), i-iv.

(37) Vaden, T. D.; Imre, D.; Beránek, J.; Shrivastava, M.; Zelenyuk, A. Evaporation kinetics and phase of laboratory and ambient secondary organic aerosol. Proc. Natl. Acad. Sci. U. S. A. 2011, 108 (6), 2190-2195.

(38) Virtanen, A.; Joutsensaari, J.; Koop, T.; Kannosto, J.; Yli-Pirila, P.; Leskinen, J.; Makela, J. M.; Holopainen, J. K.; Poschl, U.; Kulmala, M.; Worsnop, D. R.; Laaksonen, A. An amorphous solid state of biogenic secondary organic aerosol particles. Nature 2010, 467 (7317), $824-827$.

(39) Wang, B.; Lambe, A. T.; Massoli, P.; Onasch, T. B.; Davidovits, P.; Worsnop, D. R.; Knopf, D. A. The deposition ice nucleation and immersion freezing potential of amorphous secondary organic aerosol: Pathways for ice and mixed-phase cloud formation. J. Geophys. Res.: Atmos. 2012, 117 (D16), 209-220.

(40) Guo, H.; Xu, L.; Bougiatioti, A.; Cerully, K. M.; Capps, S. L.; Hite, J. R., Jr; Carlton, A. G.; Lee, S. H.; Bergin, M. H.; Ng, N. L.; Nenes, A.; Weber, R. J. Fine-particle water and $\mathrm{pH}$ in the southeastern United States. Atmos. Chem. Phys. 2015, 15 (9), 5211-5228.

(41) Lee, A. K. Y.; Abbatt, J. P. D.; Leaitch, W. R.; Li, S. M.; Sjostedt, S. J.; Wentzell, J. J. B.; Liggio, J.; Macdonald, A. M. Substantial secondary organic aerosol formation in a coniferous forest: observations of both day- and nighttime chemistry. Atmos. Chem. Phys. 2016, 16 (11), 6721-6733.

(42) Lehtipalo, K.; Sipilä, M.; Junninen, H.; Ehn, M.; Berndt, T.; Kajos, M. K.; Worsnop, D. R.; Petää, T.; Kulmala, M. Observations of Nano-CN in the Nocturnal Boreal Forest. Aerosol Sci. Technol. 2011, 45 (4), 499-509.

(43) Koop, T.; Bookhold, J.; Shiraiwa, M.; Poschl, U. Glass transition and phase state of organic compounds: dependency on molecular properties and implications for secondary organic aerosols in the atmosphere. Phys. Chem. Chem. Phys. 2011, 13 (43), 19238-19255.

(44) Shiraiwa, M.; Zuend, A.; Bertram, A. K.; Seinfeld, J. H. Gasparticle partitioning of atmospheric aerosols: interplay of physical state, non-ideal mixing and morphology. Phys. Chem. Chem. Phys. 2013, 15 (27), 11441-11453.

(45) Shiraiwa, M.; Seinfeld, J. H. Equilibration timescale of atmospheric secondary organic aerosol partitioning. Geophys. Res. Lett. 2012, 39 (24), L24801.

(46) Gaston, C. J.; Thornton, J. A.; Ng, N. L. Reactive uptake of $\mathrm{N} 2 \mathrm{O} 5$ to internally mixed inorganic and organic particles: the role of organic carbon oxidation state and inferred organic phase separations. Atmos. Chem. Phys. 2014, 14 (11), 5693-5707.

(47) Thornton, J.; Abbatt, J. P. D. Measurements of HO2 uptake to aqueous aerosol: Mass accommodation coefficients and net reactive loss. J. Geophys. Res. 2005, 110 (D8), 309-320.

(48) McNeill, V. F.; Patterson, J.; Wolfe, G. M.; Thornton, J. A. The effect of varying levels of surfactant on the reactive uptake of $\mathrm{N} 2 \mathrm{O} 5$ to aqueous aerosol. Atmos. Chem. Phys. 2006, 6 (6), 1635-1644.

(49) Badger, C. L.; Griffiths, P. T.; George, I.; Abbatt, J. P. D.; Cox, R. A. Reactive Uptake of N2O5 by Aerosol Particles Containing Mixtures of Humic Acid and Ammonium Sulfate. J. Phys. Chem. A 2006, 110 (21), 6986-6994.

(50) Anttila, T.; Kiendler-Scharr, A.; Tillmann, R.; Mentel, T. F. On the Reactive Uptake of Gaseous Compounds by Organic-Coated Aqueous Aerosols: Theoretical Analysis and Application to the
Heterogeneous Hydrolysis of N2O5. J. Phys. Chem. A 2006, 110 (35), 10435-10443.

(51) Riva, M.; Bell, D. M.; Hansen, A.-M. K.; Drozd, G. T.; Zhang, Z.; Gold, A.; Imre, D.; Surratt, J. D.; Glasius, M.; Zelenyuk, A. Effect of Organic Coatings, Humidity and Aerosol Acidity on Multiphase Chemistry of Isoprene Epoxydiols. Environ. Sci. Technol. 2016, 50 (11), 5580-5588.

(52) Lambe, A. T.; Ahern, A. T.; Williams, L. R.; Slowik, J. G.; Wong, J. P. S.; Abbatt, J. P. D.; Brune, W. H.; Ng, N. L.; Wright, J. P.; Croasdale, D. R.; Worsnop, D. R.; Davidovits, P.; Onasch, T. B. Characterization of aerosol photooxidation flow reactors: heterogeneous oxidation, secondary organic aerosol formation and cloud condensation nuclei activity measurements. Atmos. Meas. Tech. 2011, 4 (3), 445-461.

(53) Dazzi, A.; Prater, C. B. AFM-IR: Technology and Applications in Nanoscale Infrared Spectroscopy and Chemical Imaging. Chem. Rev. 2017, 117 (7), 5146-5173.

(54) Freedman, M. A.; Baustian, K. J.; Wise, M. E.; Tolbert, M. A. Characterizing the Morphology of Organic Aerosols at Ambient Temperature and Pressure. Anal. Chem. 2010, 82 (19), 7965-7972.

(55) Ault, A. P.; Guasco, T. L.; Ryder, O. S.; Baltrusaitis, J.; CuadraRodriguez, L. A.; Collins, D. B.; Ruppel, M. J.; Bertram, T. H.; Prather, K. A.; Grassian, V. H. Inside versus outside: ion redistribution in nitric acid reacted sea spray aerosol particles as determined by single particle analysis. J. Am. Chem. Soc. 2013, 135 (39), 14528-14531.

(56) Bondy, A. L.; Kirpes, R. M.; Merzel, R. L.; Pratt, K. A.; Banaszak Holl, M. M.; Ault, A. P. Atomic Force Microscopy-Infrared Spectroscopy of Individual Atmospheric Aerosol Particles: Subdiffraction Limit Vibrational Spectroscopy and Morphological Analysis. Anal. Chem. 2017, 89 (17), 8594-8598.

(57) Bondy, A. L.; Wang, B.; Laskin, A.; Craig, R. L.; Nhliziyo, M. V.; Bertman, S. B.; Pratt, K. A.; Shepson, P. B.; Ault, A. P. Inland Sea Spray Aerosol Transport and Incomplete Chloride Depletion: Varying Degrees of Reactive Processing Observed during SOAS. Environ. Sci. Technol. 2017, 51 (17), 9533-9542.

(58) Axson, J. L.; Shen, H.; Bondy, A. L.; Landry, C. C.; Welz, J.; Creamean, J. M.; Ault, A. P. Transported Mineral Dust Deposition Case Study at a Hydrologically Sensitive Mountain Site: Size and Composition Shifts in Ambient Aerosol and Snowpack. Aerosol Air Qual. Res. 2016, 16 (3), 555-567.

(59) Sobanska, S.; Falgayrac, G.; Rimetz-Planchon, J.; Perdrix, E.; Bremard, C.; Barbillat, J. Resolving the internal structure of individual atmospheric aerosol particle by the combination of Atomic Force Microscopy, ESEM-EDX, Raman and ToF-SIMS imaging. Microchem. J. 2014, 114, 89-98.

(60) Bates, K. H.; Crounse, J. D.; St. Clair, J. M.; Bennett, N. B.; Nguyen, T. B.; Seinfeld, J. H.; Stoltz, B. M.; Wennberg, P. O. Gas Phase Production and Loss of Isoprene Epoxydiols. J. Phys. Chem. A 2014, 118 (7), 1237-1246.

(61) Jacobs, M. I.; Darer, A. I.; Elrod, M. J. Rate Constants and Products of the $\mathrm{OH}$ Reaction with Isoprene-Derived Epoxides. Environ. Sci. Technol. 2013, 47 (22), 12868-12876.

(62) Eddingsaas, N. C.; VanderVelde, D. G.; Wennberg, P. O. Kinetics and Products of the Acid-Catalyzed Ring-Opening of Atmospherically Relevant Butyl Epoxy Alcohols. J. Phys. Chem. A 2010, 114 (31), 8106-8113.

(63) Weber, R. J.; Guo, H.; Russell, A. G.; Nenes, A. High aerosol acidity despite declining atmospheric sulfate concentrations over the past 15 years. Nat. Geosci. 2016, 9 (4), 282-285.

(64) Lee, S.-H.; Uin, J.; Guenther, A. B.; de Gouw, J. A.; Yu, F.; Nadykto, A. B.; Herb, J.; Ng, N. L.; Koss, A.; Brune, W. H.; Baumann, K.; Kanawade, V. P.; Keutsch, F. N.; Nenes, A.; Olsen, K.; Goldstein, A.; Ouyang, Q. Isoprene suppression of new particle formation: Potential mechanisms and implications. J. Geophys. Res.: Atmos. 2016, 121 (24), 14621-14635.

(65) Hu, W.; Palm, B. B.; Day, D. A.; Campuzano-Jost, P.; Krechmer, J. E.; Peng, Z.; de Sá, S. S.; Martin, S. T.; Alexander, M. L.; Baumann, K.; Hacker, L.; Kiendler-Scharr, A.; Koss, A. R.; de Gouw, J. A.; Goldstein, A. H.; Seco, R.; Sjostedt, S. J.; Park, J. H.; Guenther, A. B.; 
Kim, S.; Canonaco, F.; Prévôt, A. S. H.; Brune, W. H.; Jimenez, J. L. Volatility and lifetime against $\mathrm{OH}$ heterogeneous reaction of ambient isoprene-epoxydiols-derived secondary organic aerosol (IEPOX-SOA). Atmos. Chem. Phys. 2016, 16 (18), 11563-11580.

(66) Budisulistiorini, S. H.; Nenes, A.; Carlton, A. G.; Surratt, J. D.; McNeill, V. F.; Pye, H. O. T. Simulating Aqueous-Phase IsopreneEpoxydiol (IEPOX) Secondary Organic Aerosol Production During the 2013 Southern Oxidant and Aerosol Study (SOAS). Environ. Sci. Technol. 2017, 51 (9), 5026-5034.

(67) Liggio, J.; Li, S.-M.; Vlasenko, A.; Stroud, C.; Makar, P. Depression of Ammonia Uptake to Sulfuric Acid Aerosols by Competing Uptake of Ambient Organic Gases. Environ. Sci. Technol. 2011, 45 (7), 2790-2796.

(68) Kourtchev, I.; Ruuskanen, T.; Maenhaut, W.; Kulmala, M.; Claeys, M. Observation of 2-methyltetrols and related photo-oxidation products of isoprene in boreal forest aerosols from Нyyti\&\#228;1\&\#228;, Finland. Atmos. Chem. Phys. 2005, 5 (10), 27612770 .

(69) Ye, Q.; Robinson, E. S.; Ding, X.; Ye, P.; Sullivan, R. C.; Donahue, N. M. Mixing of secondary organic aerosols versus relative humidity. Proc. Natl. Acad. Sci. U. S. A. 2016, 113 (45), 12649-12654. 